\title{
Timing of uplift in the Zagros belt/Iranian plateau and accommodation of late Cenozoic Arabia-Eurasia convergence
}

\author{
F. MOUTHEREAU*
}

UPMC Univ Paris 06, UMR 7193, Institut des Sciences de la Terre et de l'Environnement de Paris, F-75005, Paris, France, and CNRS, UMR 7193, Institut des Sciences de la Terre de Paris, F-75005, Paris, France

(Received 9 November 2010; accepted 25 January 2011; first published online 18 April 2011)

\begin{abstract}
The motion of Arabia was stable with respect to Eurasia over the past $22 \mathrm{Ma}$. Deformation and exhumation in the Zagros is seen to initiate at the same time as argued by new detrital thermochronologic constraints and increasing accumulation rates in synorogenic sediments. A recent magnetostratigraphic dating of the Bakhtyari conglomerates in the northern Fars region of the Zagros further suggests that shortening and uplift in the Zagros Folded Belt accelerated after 12.4 Ma. Available temporal constraints from surrounding collision belts indicate that shortening and uplift focused in regions bordering the Iranian plateau to the south between 15 and $5 \mathrm{Ma}$. As boundary velocity was kept constant this requires concomitant decreasing strain rates in the Iranian plateau. Slab detachment has been proposed to explain the observed changes as well as mantle delamination, but the insignificant change in the Arabian slab motion and lack of unambiguous constraints make both hypotheses difficult to account for. It is proposed based on a review of shortening estimates provided throughout the Arabia-Eurasia collision that the total $440 \mathrm{~km}$ of convergence predicted by geodesy and plate reconstruction over the past 22 Ma can be accounted for by distributed shortening. I suggest that the topography and expansion of the Iranian plateau over Late Miocene-Pliocene time can be reproduced by the progressive thickening of the originally thin Iranian continental lithosphere presumably thermally weakened during the Eocene extensional and magmatic event.
\end{abstract}

Keywords: Zagros, plateau, uplift, shortening.

\section{Introduction}

Knowledge of the distribution of Cenozoic shortening in the Zagros collision in Iran is critical to better understand how the Arabian plate motion was accommodated during the collision with the overriding Eurasian plate. Combined with the precise timing of deformational events, it is key in linking the kinematic development of the Zagros Folded Belt to the growth of the Iranian plateau.

A significant number of publications have brought new insights on the current and Quaternary tectonics of the Zagros mountain belt (Nilforoushan et al. 2003; Masson et al. 2005; Vernant et al. 2004; Walpersdorf et al. 2006; Oveisi et al. 2009) and on the deep geophysical settings beneath the Iranian plateau and the Zagros belt (Hatzfeld et al. 2003; Maggi \& Priestley, 2005; Paul et al. 2006; Kaviani et al. 2009; Hatzfeld \& Molnar, 2010). Allen, Jackson \& Walker (2004) pointed out that major reorganization of the ArabiaEurasia collision has occurred in the past $5 \pm 2 \mathrm{Ma}$ to account for the rates of motion along major active faults. However, thermochronometric data (Fig. 1) from the Zagros foreland sediments argued for acceleration of denudation c. $25 \mathrm{Ma}$ (Homke et al.2010; S. Khadivi, unpub. Ph.D. thesis, Univ. Pierre et Marie Curie, 2010), and thrusting/folding activity in the northern Zagros

*E-mail: frederic.mouthereau@upmc.fr belt seems to have been mostly initiated in EarlyMiddle Miocene time (Gavillot et al. 2010; Khadivi et al. 2010). Overall, constraints from the Zagros are rather in agreement with the stable northward drift of the Arabian plate since $22 \mathrm{Ma}$ (ArRajehi et al. 2010).

The deep structure (Fig. 2) shows a $45 \mathrm{~km}$ thick Arabian crust beneath the Zagros Folded Belt and the High Zagros (Paul et al. 2006, 2010). The good agreement with the unthickened portion of the Arabian margin (Gök et al. 2008) indicates that the crust has not yet been significantly thickened beneath the Zagros Folded Belt. By contrast, the deepening of the Moho to a depth of $70 \mathrm{~km}$ beneath the SanandajSirjan Metamorphic Belt illustrates the significant underthrusting of the Arabian margin and the focused accretion by underplating beneath the upper Iranian plate (Fig. 2). The thickening of the lithosphere is supported by seismological evidence indicating that there is a thick lithosphere 'core' beneath the Zagros (Priestley \& McKenzie, 2006). North of the SanandajSirjan Zone, the Iranian continental block displays a crustal thickness of $\sim 50 \mathrm{~km}$ and a warm upper mantle lithosphere down to a depth of $100 \mathrm{~km}$. This anomalously thin lithosphere might be caused by the partial delamination of a continental lithosphere following the thickening of the continent during the protracted plate convergence (Maggi \& Priestley, 2005; Hatzfeld \& Molnar, 2010). But a more accurate 

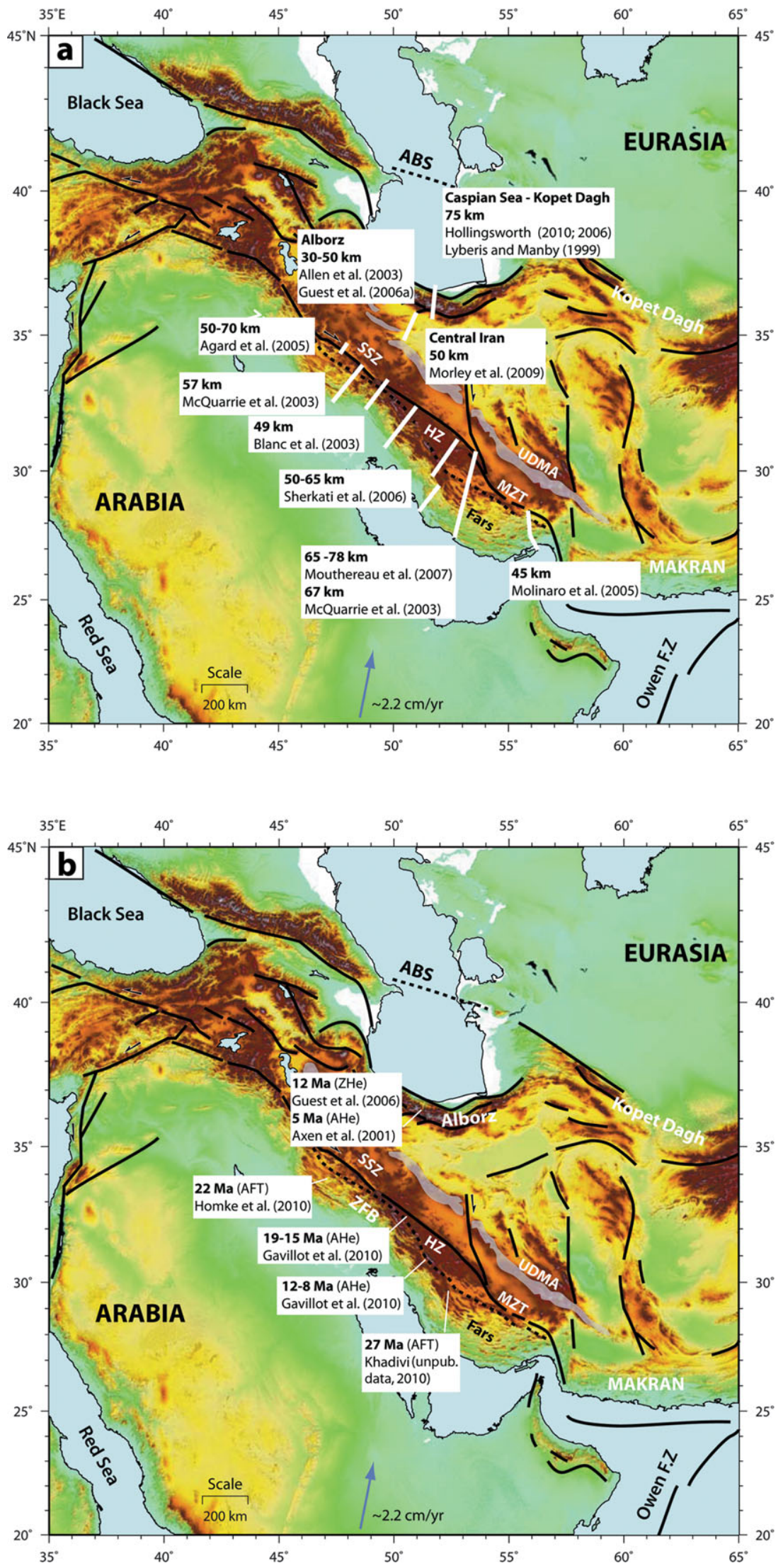

Figure 1. (Colour online) (a) Geodynamic setting of the Arabia-Eurasia collision and the distribution of long-term shortening and (b) ages of the most recent exhumational events according to the thermochronometer used (AFT - apatite fission-track; AHe - (U-Th)/He dating on apatite; $\mathrm{ZHe}-(\mathrm{U}-\mathrm{Th}) / \mathrm{He}$ dating on zircon $)$. Main topographic and tectonic features of the Arabia-Eurasia convergence are also shown. White lines correspond to the location of balanced cross-sections from which amounts of shortening have been estimated. Black lines display major active faults. The current Arabian-Eurasian plate convergence is shown as a grey (blue) arrow after Vernant et al. (2004). Abbreviations are Zagros Folded Belt (ZFB), High Zagros (HZ), Main Zagros Thrust (MZT), Sanandaj-Sirjan Zone (SSZ), Urumieh-Dokhtar Magmatic Arc (UDMA), Apsheron-Balkan Sill (ABS). 


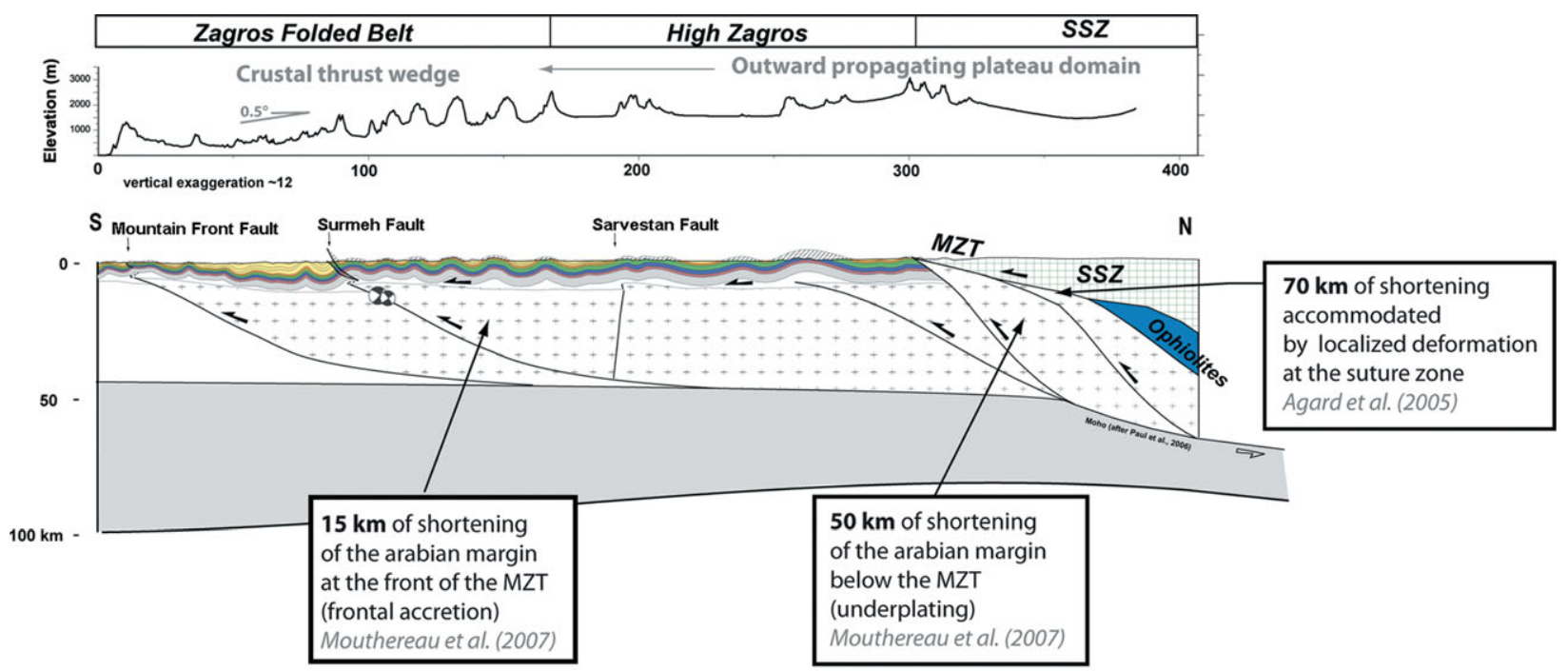

\begin{tabular}{|c|c|c|}
\hline $\begin{array}{l}\text { Eiocene-Pliocene } \\
\text { Fars Group (Gashsaran Fm, Mishan Fm } \\
\text { including Guri mb, Agha Jari Fm) }\end{array}$ & $\begin{array}{l}\square \text { Lower-Upper Cretaceous } \\
\text { ( Gadvan Fm, Dariyan Fm, Kazhdumi Fm) }\end{array}$ & $\begin{array}{l}\text { Upper Palaeozoic and Permian } \\
\text { (Faraghan and Dalan Fm) }\end{array}$ \\
\hline$\square \begin{array}{l}\text { Eocene-Oligocene-U. Miocene } \\
\text { (Jahrom Fm, Asmari Fm) }\end{array}$ & $\begin{array}{l}\text { Jurassic } \\
\text { (Surmeh Fm, Gotnia Fm, Fahliyan Fm) }\end{array}$ & $\square \begin{array}{l}\text { Upper Proterozoic- Middle Cambrian } \\
\text { (Hormuz Fm) }\end{array}$ \\
\hline $\begin{array}{l}\text { Upper Cretaceous-Paleocene } \\
\text { (Sarvak Fm, Gurpi Fm, Pabdeh Fm) }\end{array}$ & $\square \begin{array}{l}\text { Triassic } \\
\text { (Kahnet Kat Fm, Neyriz Fm, Dashtak Fm) }\end{array}$ & \\
\hline$\square$ Arabian continental basement & $\Psi$ Iranian continental basement & Tethyan oceanic basement \\
\hline
\end{tabular}

Figure 2. (Colour online) Distribution of shortening across the Zagros belt and outward migration of plateau uplift. The balanced cross-section of the Zagros in the Fars region is after Mouthereau et al. (2007). See Figure 1 for location and abbreviations.

velocity estimate does not support mantle delamination (Kaviani et al. 2007), and more generally there is no definitive evidence supporting the convective removal of lithosphere beneath the plateau. On the other hand, upwelling of asthenospheric mantle controlled by slab retreat may provide an explanation for such thin lithosphere as suggested by several geological constraints (Vincent et al. 2005; Verdel et al. 2007; Morley et al. 2009).

A kinematic link between the recent tectonic evolution of the Zagros Folded Belt and the Iranian plateau growth can be suggested based on several lines of evidence. The southern edge of the Iranian plateau is coincident, in the Fars region of Iran, with the northern edge of the Zagros Mountains outlined by a cumulative topographic step and structural elevation of $\sim 2 \mathrm{~km}$ (Figs 2,3). Such a morphology indicates that the regional Zagros topography was built by basement thrust units, the most active ones being spaced $\sim 80 \mathrm{~km}$ apart (Mouthereau, Lacombe \& Meyer, 2006; Mouthereau et al. 2007). Combined with evidence of widespread seismicity over the length of the outer Zagros Folded Belt, this supports a model in which the topography is balanced by a crustal-scale critically tapering orogenic wedge.

By contrast, the High Zagros region forms an elevated low-relief area that is morphologically not distinguishable from the southern edge of the Iranian plateau (Figs 2, 3). This suggests that part of the
Zagros collision belt has been uplifted owing to its incorporation into the Iranian plateau. This relationship implies that the growth history of the plateau cannot be understood outside the context of the kinematic history of the Zagros Folded Belt.

In this short paper, by providing a review of the recent advances on the temporal evolution and spatial distribution of shortening and exhumation in the Zagros belt and other compressional domains surrounding the Arabia-Eurasia collision, I aim at highlighting the timing and mechanisms of Iranian plateau growth. Specifically, I focus on the distribution of shortening over the past $22 \mathrm{Ma}$, a period during which the northward motion of Arabia was stable.

\section{Regional geological background}

The NW-SE-trending Zagros orogeny, which is part of the much larger Alpine-Himalayan orogenic system, extends some $2000 \mathrm{~km}$ from the East Anatolian fault in eastern Turkey to the Makran subduction in southern Iran (Fig. 1). A GPS-derived velocity model shows present-day convergence rates between Arabia and Eurasia of 19-26 mm yr ${ }^{-1}$ (McClusky et al. 2003; Vernant et al. 2004). In the next Sections, I briefly present the main geological features of the Zagros collision including the Zagros belt, the Sanandaj-Sirjan belt and the Urumieh-Dokhtar volcanic arc. 


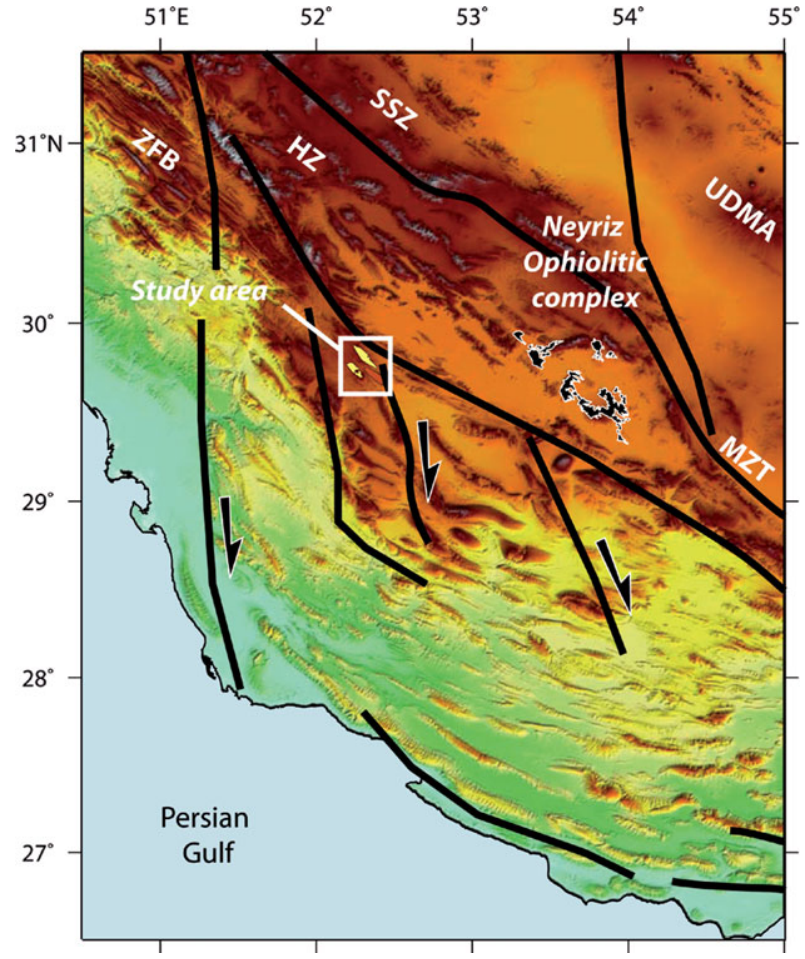

Figure 3. (Colour online) Topographic map of the Fars area (SRTM $90 \mathrm{~m}$ digital elevation data; http://srtm.csi.cgiar.org) showing the location of the area studied for magnetostratigraphy and thermochronometry (Derak anticline) by Khadivi et al. (2010) and S. Khadivi (unpub. Ph.D. thesis, Univ. Pierre et Marie Curie, 2010). The Neyriz Ophiolitic Complex is currently exposed as klippen above the deformed sedimentary units of the High Zagros (HZ). The metamorphic belt of the Sanandaj-Sirjan Zone (SSZ), the Urumieh-Dokhtar Magmatic Arc (UDMA), the Zagros Folded Belt (ZFB) and Main Zagros Thrust (MZT) are also labelled.

\section{2.a. Zagros Folded Belt (ZFB)}

The Zagros Folded Belt makes up the currently active accretionary wedge of the Zagros collision. It is characterized by remarkably regular, long and largewavelength NW-trending concentric folds (Figs 2, 3). They have probably resulted from buckling and subsequent detachment folding of a $12 \mathrm{~km}$ thick sediment cover enabled by the detachment in the Cambrian Hormuz salt (Lacombe et al. 2007; Mouthereau et al. 2007). Active faulting is rare but does occur in the competent cover as argued from recent seismological studies (Adams et al. 2009; Nissen et al. 2010; Roustaei et al. 2010). The pre-Cambrian basement of the Arabian margin is also actively deforming, as indicated by a number of morphotectonic observations in the Fars (Molinaro et al. 2004; Lacombe et al. 2006; Mouthereau et al. 2007) and seismicity (Talebian \& Jackson, 2004). Basement-involved shortening is also mechanically required to maintain the regional topography (e.g. Mouthereau, Lacombe \& Meyer, 2006) and it is confirmed by the most recent analysis of individual earthquakes revealing active reverse faulting at depths of 10-30 km (Roustaei et al. 2010).
The external Zagros can be divided in two substructural domains. The first one is the High Zagros (HZ) belt characterized, in the Fars region, by Mesozoic carbonates overthrust by the radiolaritic series and ultramafic bodies of the Neyriz ophiolitic complex, considered allochthonous fragments of the western Neo-Tethyan ocean (Figs 2, 3) (Stocklin, 1968; Golonka, 2004). The second is the Zagros Folded Belt (ZFB) sensu stricto, also called the Zagros Simply Folded Belt (ZSFB), with folded Miocene to Pliocene synorogenic strata (Fig. 2).

\section{2.b. Sanandaj-Sirjan Zone (SSZ)}

The Sanandaj-Sirjan Zone, located to the north of the Main Zagros Thrust (MZT), represents the internal tectonomagmatic and metamorphic part of the Zagros belt (Figs 1-3).It is made of sedimentary and metamorphic (HP/LT and HT/LP facies) Palaeozoic to Cretaceous rocks formed in an accretionary prism located to the south of the Iranian microcontinent separated from Gondwanaland during Late Jurassic time (Berberian \& Berberian, 1981; Golonka, 2004). Alternative interpretations consider it to be the metamorphic core of a larger Zagros accretionary complex built by the thickening of distal crustal portions of the Arabian margin (Shafaii Moghadam, Stern \& Rahgoshay, 2010). During the second half of the Mesozoic (Middle Jurassic-Early Cretaceous), part of the Sanandaj-Sirjan Zone was an active Andeanlike margin characterized by calc-alkaline magmatic activity in which mainly andesitic and gabbroic intrusions were emplaced (Berberian \& Berberian, 1981). Magmatism resumed in Paleocene-Eocene time, as evidenced by gabbroic intrusions (Leterrier, 1985; Mazhari et al. 2009) or granitic intrusions of this age (Rachidnejad-Omran et al. 2002).

\section{2.c. Urumieh-Dokhtar Magmatic Arc (UDMA)}

The Urumieh-Dokhtar Magmatic Arc (UDMA; Fig. 1) is interpreted as a subduction-related arc that has been active from Late Jurassic time to the present (Berberian \& King, 1981; Berberian et al. 1982). The climax of magmatic activity can be dated to Middle Eocene time (Berberian \& King, 1981). The volcanic rocks of the Urumieh-Dokhtar Magmatic Arc are composed of voluminous tholeiitic, calc-alkaline and K-rich alkaline magmatic rocks with associated pyroclastic and volcanoclastic successions. Magmatism resumed in Pliocene time and the Quaternary as indicated by lavas and pyroclastic rocks associated with the volcanic cones of alkaline and calc-alkaline nature (Berberian \& Berberian, 1981). The Plio-Quaternary volcanism was suggested to result from the modification of geothermal gradients that was tentatively related to lithosphere delamination beneath the Iranian plateau (Hatzfeld \& Molnar, 2010) or slab break-off (Omrani et al. 2008). 


\section{Timing of shortening, collision and uplift in the} Zagros belt

3.a. Short-term, long-term shortening and the Arabia-Eurasia convergence

Comparison between a recent synthesis of GPS data (ArRajehi et al. 2010) and reconstruction of past plate motions (McQuarrie et al. 2003) shows that the Arabia-Eurasia convergence occurred at a rate of $\sim 20 \mathrm{~km} \mathrm{Ma}^{-1}$ (Tatar et al. 2002; Hatzfeld et al. 2003; Nilforoushan et al. 2003; Vernant et al. 2004) since at least $22 \mathrm{Ma}$, following the separation of Arabia from Africa (Nubia), the onset of rifting in the Red Sea and the Aden Gulf and the increase in plate coupling in the Zagros collision (e.g. Mouthereau et al. 2007).

A total convergence of $440 \mathrm{~km}$ should have been accommodated by distributed collisional shortening and subduction (i.e. underthrusting of the continental lithosphere) in the surrounding collision belts since $22 \mathrm{Ma}$ including the Zagros to the south, the Alborz and the Kopet-Dagh to the north, and by $\mathrm{N}-\mathrm{S}$ shortening accommodated by reverse and/or strike-slip faulting in Central Iran (e.g. Allen et al. 2011 and references therein).

For the Zagros alone, geodetic measurements argue for current shortening rates of $7-10 \mathrm{~mm} \mathrm{yr}^{-1}$ (Tatar et al. 2002; Nilforoushan et al. 2003; Vernant et al. 2004), with most of the current shortening accumulating within the lower elevation parts of the Zagros Folded Belt (Walpersdorf et al. 2006) in agreement with geomorphological observations (Oveisi et al. 2009), thus fitting the seismicity distribution well. By comparison, all published balanced cross-sections, irrespective of differences in structural interpretations (Blanc et al. 2003; McQuarrie, 2004; Sherkati \& Letouzey, 2004; Molinaro et al. 2005; Mouthereau et al. 2007), account for as much as 50-70 km of shortening. By assuming that the initiation of shortening dates back to $22 \mathrm{Ma}$, such a shortening accounts for less than half the current shortening rates. On the other hand, a finite shortening of $70 \mathrm{~km}$ would be achieved in $\sim 7 \mathrm{Ma}$ to be consistent with the current shortening rates. Based on these geodetic data, Allen, Jackson \& Walker (2004) therefore inferred that the main episode of crustal thickening in the Zagros should be more recent than $7 \mathrm{Ma}$. However, because of the stability of the Arabian plate motion since $22 \mathrm{Ma}$ (McQuarrie et al. 2003; ArRajehi et al. 2010), forces related to the assumed changes at $\sim 5 \mathrm{Ma}$ must have been limited because they did not alter the slab pull forces acting on the Arabian plate motion. In this context, the timing of development of the High Zagros hence appears key in constraining the Late Cenozoic distribution of shortening in the Arabian-Eurasian plate convergence and the mechanism of Iranian plateau growth. In the next Sections, I specifically explore constraints on the collision onset, the timing of deformation in the Zagros belt and the temporal evolution of exhumation in the High Zagros.

\section{3.b. Initiation of Arabia-Eurasia collision}

The Arabian and Eurasian plates started to collide along the Bitlis thrust zone in Early Miocene time (c. $20 \mathrm{Ma}$ ) following the consumption of the last remaining oceanic lithosphere (Okay, Zattin \& Cavazza, 2010). Along the Zagros suture zone, the stratigraphic/structural relationships also argue for final closure of the Neo-Tethyan ocean by Early Miocene time c. $20 \mathrm{Ma}$ (e.g. Agard et al. 2005). This is in line with evidence supporting the coeval onset of foreland subsidence (Mouthereau et al. 2007) and stress build-up in the Arabian platform (Ahmadhadi, Lacombe \& Daniel, 2007). Consistently, the recent reevaluation of the stratigraphy of the coarse-grained facies in the Zagros foreland basin shows that the onset of coarsening-upward sedimentation linked to the exhumation of the hangingwall of the Main Zagros Thrust occurred during Late Oligocene-Early Miocene time (Fakhari et al. 2008). This is also indicated by the finding of Mesozoic to Eocene detrital apatite fission-track (AFT) cooling ages in Miocene foreland sediments compatible with the Sanandaj-Sirjan Zone cooling history (S. Khadivi, unpub. Ph.D. thesis, Univ. Pierre et Marie Curie, 2010; see also Fig. 6). On the other hand, the decrease in or end of magmatism in Central Iran supports that initial collision of Arabia occurred in Late Eocene time (e.g. Vincent et al. 2005; Allen \& Armstrong, 2008). On the Arabian margin, a Middle Eocene-Late Oligocene or Late Eocene-Early Miocene unconformity recognized in the carbonaceous sediment succession of the Zagros (James \& Wynd, 1965; Berberian \& King, 1981) and the erosional or non-depositional hiatus described to the NW, in the Lorestan area, in the Middle-Late Eocene interval (Homke et al. 2009) indirectly support this timing. In summary, constraints on the timing of Neo-Tethyan ocean consumption, Zagros sediment provenance and arc magmatism in the Iranian microplate support initiation of the Arabia-Eurasia collision between 35 and $20 \mathrm{Ma}$.

\section{3.c. Timing of deformation in the Zagros Folded Belt}

The unambiguous dating of deformation in the fold-thrust belt requires the preservation of tectonic/stratigraphic relationships such as synfolding sediments and associated geometries like growth strata. This is only possible in regions where regional subsidence and sedimentation supplied by exhuming mountain ranges are high enough to allow wedge-top basins to develop. Such geometries are observed in some parts of the Zagros and when combined with magnetostratigraphy allow accurate determination of the age of deformation as presented in recent papers (Homke et al. 2004; Khadivi et al. 2010).

Hereafter, I focus on the dating of the first synorogenic deposits in the northern Zagros. The studied sections are located (Fig. 4) on the northern flank of the Chahar-Makan syncline at an altitude of $\sim 2500 \mathrm{~m}$, 

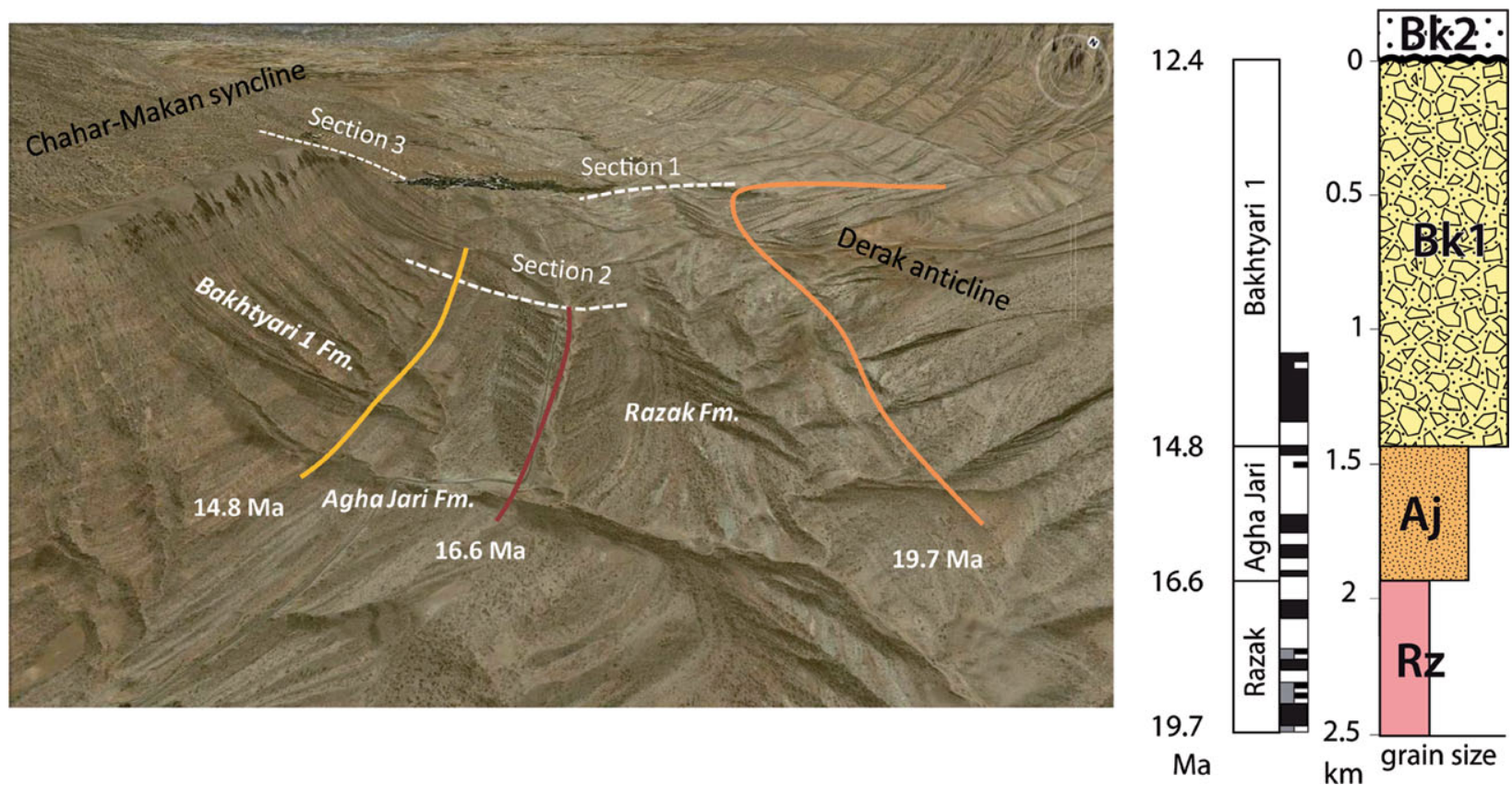

Figure 4. (Colour online) Position of magnetostratigraphic sections measured in the northern flank of the Chahar-Makan syncline and age of the main formation boundaries obtained after Khadivi et al. (2010). On the left, sections are shown on 3D satellite view of the studied area (See Fig. 3 for location). On the right, the total sedimentary section $2.5 \mathrm{~km}$ thick is shown with age constraints. The age of the youngest Bakhtyari 1 conglomerate is derived from the accumulation rates obtained from magnetostratigraphy (modified after Khadivi et al. 2010).
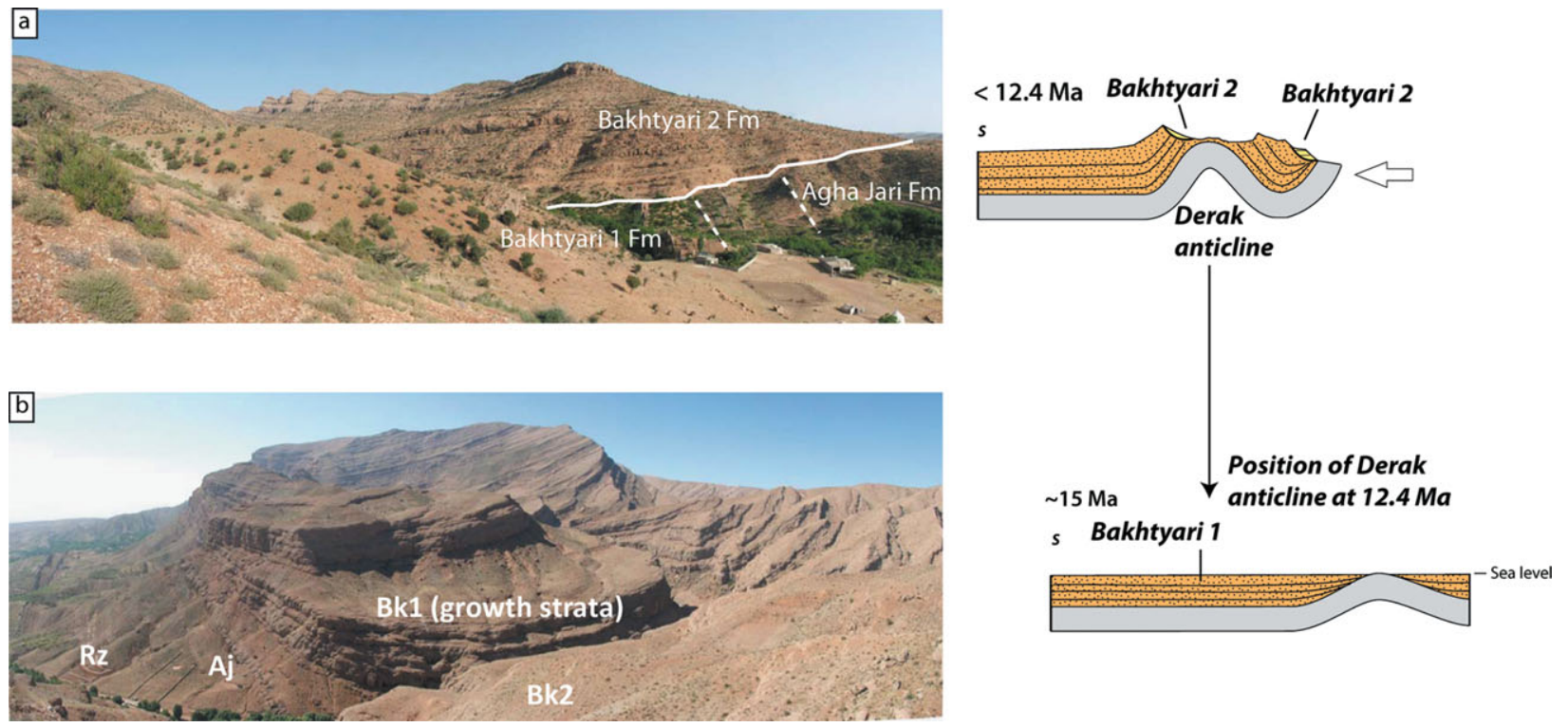

Figure 5. (Colour online) (a) Structural relationships between Bakhtyari 2 (Bk2) and Bakhtyari 1 (Bk1) conglomerates and (b) growth strata geometry on the northern flank of the Derak anticline. Interpretation of these geometries in terms of the sequence of folding is given on the right-hand side.

$20 \mathrm{~km}$ to the NW of Shiraz, in the Fars province of Iran. The lowest strata, $500 \mathrm{~m}$ thick, are sediments deposited in a coastal sabkha environment and correspond to the Razak Formation, the base of which is dated to 19.7 Ma. Above are the $400 \mathrm{~m}$ thick deltaic sandstones of the Agha Jari Formation dated to $16.6 \mathrm{Ma}$ in agreement with the finding of the nannoplankton association that indicates the NN4 biozone. Above, the lowest Bakhtyari 1 unit is made of alluvial conglomerates deposited close to sea-level, as revealed by the underlying marine Agha Jari sediments and by marine incursions in the Oligocene-Miocene Bakhtyari conglomerates deposited in the High Zagros (Fakhari et al. 2008; Gavillot et al. 2010). Growth strata found on the northern flank of the Derak anticline confirms that the Bakhtyari conglomerates were deposited during folding, therefore providing a minimum age of $14.8 \mathrm{Ma}$ for the onset of folding in the northern Zagros belt 
(Fig. 5). However, this stage of deformation does not represent the main stage of folding as the Razak Fm, Agha Jari Fm and the Bakhtyari $1 \mathrm{Fm}$ have been tilted by the subsequent growth of the Derak fold and are currently cropping out in the ChaharMakan and Qalat synclines. This second folding is outlined by a major angular unconformity between the flat-lying or slightly $\mathrm{N}$-dipping conglomeratic layers of the Bakhtyari 2 Formation and underlying Bakhtyari 1 Formation. By considering the total cropping-out thickness of Bakhtyari 1 conglomerates and extrapolating with accumulation rates derived from magnetostratigraphy, I obtained a maximum age of 12.4 Ma for the second major stage of folding. Taking into account age uncertainties on the unconformity, this age appears not significantly different from other magnetostratigraphic constraints obtained for folding initiation at the mountain front dated at $7.6 \mathrm{Ma}$ in the Lorestan area (Homke et al. 2004) or from the inner Zagros belt where folding is dated to $11 \mathrm{Ma}(\mathrm{H}$. Emami, unpub. Ph.D. thesis, Univ. de Barcelona, 2008). In the hangingwall of the Dinar thrust (High Zagros), detrital apatite (U-Th)/He ages of 11.6-8.8 Ma on folded Bakhtyari conglomerates (Gavillot et al. 2010) provide indirect constraints on the age of deformation. Overall, stratigraphic constraints reveal that shortening was initially accumulated in the northern Zagros in Early Miocene time, close to the suture zone, and subsequently propagated southward during latest Miocene time.

\section{3.d. Uplift and exhumation in the Zagros Folded Belt and the High Zagros}

In addition to dating deformation in the Zagros, it is equally important to track the elevation changes back in time. Based on the youngest marine sediments dated in Iran, it is beyond doubt that both the Zagros and the Iranian plateau were still below sea-level until Early Miocene time (Schuster \& Wielandt, 1999; Harzhauser et al. 2007), and one can also be confident that until $\sim 15 \mathrm{Ma}$ the northern Zagros Folded Belt was close to sea-level (Khadivi et al. 2010).

Helium dating on detrital apatites from the Bakhtyari conglomerates deposited in the High Zagros and an age-elevation profile of the Lajin thrust (Fig. 1b) tells us that rapid cooling took place in Early Miocene time from $19 \mathrm{Ma}$ to $15 \mathrm{Ma}$ (Gavillot et al. 2010). Furthermore, the pre-collisional zircon (U-Th)/He ages presented in the same study indicate that the maximum exhumation in the High Zagros was limited to $7-9 \mathrm{~km}$, which is consistent with the average thickness of the Meso-Cenozoic sediment cover and the scarcity of Palaeozoic rocks cropping out in the High Zagros. They deduced from the hangingwall of High Zagros thrusts local exhumation rates of the order of $0.3-0.4 \mathrm{~km} \mathrm{Ma}^{-1}$.

Low-temperature AFT thermochronology carried out on older Miocene foreland sediments of the Zagros Folded Belt (Figs 1b, 6) indicates that rapid cooling

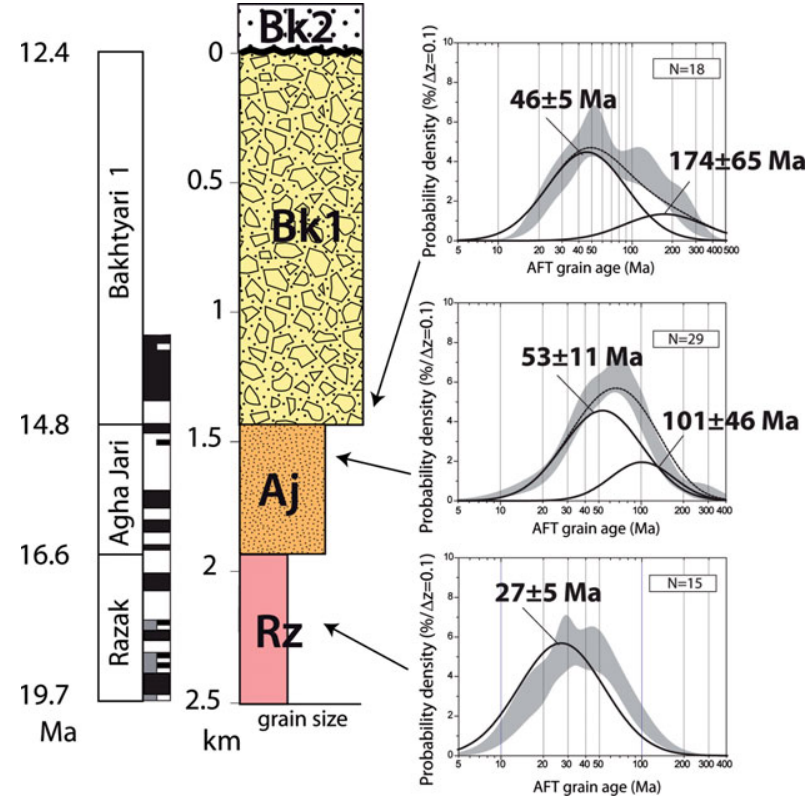

Figure 6. (Colour online) Probability density distribution of fission-track ages obtained on detrital apatites $(\mathrm{N}$ is the number of grains) from the Miocene sediments of the Chahar-Makan section presented in Figure 4 (modified after S. Khadivi, unpub. Ph.D. thesis, Univ. Pierre et Marie Curie, 2010) and dated by Khadivi et al. (2010). All grain-age populations are interpreted as cooling ages and as such indicate exhumational events. The age at $27 \mathrm{Ma}$ is interpreted to be related to the rapid exhumation owing to thickening associated with the Zagros collision. Eocene and Mesozoic ages correspond to grains cooled in the Sanandaj-Sirjan Metamorphic Belt and deposited into the Miocene foreland basin, thus revealing the suturing along the Main Zagros Thrust and the onset of the Zagros collision.

occurred between $27 \mathrm{Ma}$ (depositional age of the Razak Fm is $19.7 \mathrm{Ma}$ in the Chahar-Makan syncline) and $22 \mathrm{Ma}$ (depositional age of the Lower Agha Jari Fm is 12.8 Ma in the Zarrinabad syncline) in the High Zagros (Homke et al. 2010; S. Khadivi, unpub. Ph.D. thesis, Univ. Pierre et Marie Curie, 2010). Taking into account a closure temperature of $110^{\circ} \mathrm{C}$ and a geotherm of 15 $24{ }^{\circ} \mathrm{C} \mathrm{km}^{-1}$ (Mouthereau, Lacombe \& Meyer, 2006; Gavillot et al. 2010; Homke et al. 2010), one estimates that $4.5-7 \mathrm{~km}$ were exhumed during Early Miocene time.

The preservation of unreset Mesozoic, Eocene or Early Miocene grain-age populations limits the exhumation in the Chahar-Makan syncline to $2.5 \mathrm{~km}$, which is the thickness of the synorogenic Miocene sediments (Fig. 6). Since folding started later than 12.4 Ma, one can derive a minimum exhumation rate of $0.2 \mathrm{~km} \mathrm{Ma}^{-1}$, comparable to the sedimentary accumulation rates of $\sim 0.2-0.3 \mathrm{~km} \mathrm{Ma}^{-1}$ in the $12-$ $3 \mathrm{Ma}$ distal foreland basin succession at the mountain front (Homke et al. 2004) and rates of $0.2-0.6 \mathrm{~km}$ $\mathrm{Ma}^{-1}$ in the 20-14 Ma proximal foreland sediments (Khadivi et al. 2010). Taking into consideration the fact that accumulation rates are underestimated because decompaction is not accounted for, I see no significant 
difference between erosion and sedimentation rates during the Miocene.

To summarize, thermochronologic data from Miocene sediments show rapid exhumation near the suture zone after $25 \mathrm{Ma}$ (Figs 1b, 6). As a consequence this region was actively uplifting above sea-level owing to the thickening of the Arabian crust. Further evidence of exhumation at this time in the Sanandaj-Sirjan Zone is provided by the occurrence of detrital zircons derived from the overriding Iranian microplate and deposited in the Upper Oligocene conglomerates (Horton et al. 2008). Such exhumation is also suggested by one AFT grain-age population of $27 \mathrm{Ma}$ reported from a gneiss sample of the Dorud metamorphic complex of the Sanandaj-Sirjan Zone (Homke et al. 2010). Propagation of shortening in the Zagros Folded Belt and uplift associated with basement-involved thrusting did not occur before $12.4 \mathrm{Ma}$ in the Fars region, thus placing constraints on the timing of plateau uplift.

\section{Distribution of shortening and uplift in the Zagros, Iranian plateau and the Alborz}

\section{4.a. Distribution of shortening, underthrusting and underplating in the Zagros}

The shortening within the Zagros belt appears highly inhomogeneously distributed between the Zagros Folded Belt to the south and the north where it is accommodated below the Sanandaj-Sirjan Zone (Figs 1a, 2). Among the total shortening accommodated in the Zagros belt, only $5 \%(15 \mathrm{~km})$ is taken up in the Zagros Folded Belt (Mouthereau et al. 2007). Next, I verify whether this value, obtained in the Fars province, is acceptable in the light of geophysical data and observed topography. Provided that the initial crustal thickness $H_{c}$ is known and the amount of shortening (a $-b$ ), where $a$ and $b$ are the initial and the final lengths of the studied geological section, respectively, can be derived, the resulting Airy-compensated topography $h$ is given by

$$
h=\frac{(\mathrm{a}-\mathrm{b}) H_{c} \Delta \rho}{\mathrm{b} \rho_{m}}
$$

where $\Delta \rho=\rho_{m}-\rho_{c}$ with $\rho_{c}=2800 \mathrm{~kg} / \mathrm{m}^{3}$ and $\rho_{m}=3330 \mathrm{~kg} / \mathrm{m}^{3}$.

In the first case, by assuming conservation of mass and in-plane deformation, and the fact that the related topographic load wavelength (i.e. $100 \mathrm{~km}$ ) is too small with respect to the elastic thickness of the Arabian plate $\left(\mathrm{T}_{\mathrm{e}}=50 \mathrm{~km}\right.$; Snyder \& Barazangi, 1986) to be compensated by a crustal root (Paul et al. 2006, 2010), the predicted topographic elevation of $2.25 \mathrm{~km}$ is simply obtained by equating initial and final crustal areas with $H_{c}=45 \mathrm{~km}$. Even though a better result (i.e. elevation of $1.6 \mathrm{~km}$ ) can be obtained for a lower shortening of $3 \%(10 \mathrm{~km})$, this calculation shows that only a small amount of shortening can account for the
Zagros Folded Belt topography. In contrast, any greater shortening estimates would have resulted in unrealistic topographic elevations.

Northward, beneath the Sanandaj-Sirjan Zone, the shortening of the Arabian crust is seen to increase up to $37 \%(50 \mathrm{~km})$ and is thought to result from duplexing (Mouthereau et al. 2007). Prior to accretion of Arabian material below the Sanandaj-Sirjan Zone, during the early stages of the collision, the thinner and more distal portion of the Arabian margin was underthrusted. This is attested by receiver functions in the NW Zagros, revealing that the underthrusting of the Arabian crust below the obducted ophiolitic complex and Sanandaj-Sirjan Zone might have been as large as $250 \mathrm{~km}$ (Paul et al. 2010). However, only a part of it has been accommodated after Miocene time and hence can be considered in our calculation. Moreover, in the NW Zagros, Agard et al. (2005) showed that $50-70 \mathrm{~km}$ of Miocene shortening was taken up in the vicinity of, or at, the suture zone mainly within the ophiolitic sheets and thrust slices of the southern Sanandaj-Sirjan belt. These 50-70 km can represent $20-30 \%$ of the total amount of shortening absorbed during the underthrusting of the Arabian margin as inferred from geophysics. As a result, they are not equivalent to the $37 \%(50 \mathrm{~km})$ of Mouthereau et al. (2007) accommodated by duplexing below the Main Zagros Thrust and instead must be added to them. One deduces that a total shortening of $135 \mathrm{~km}$ occurred near the suture zone and has likely been distributed as follows: $15 \mathrm{~km}$ in the Zagros Folded Belt (post$12.4 \mathrm{Ma}$ ), $50 \mathrm{~km}$ by duplexing (post-25 Ma) and up to $70 \mathrm{~km}$ by underthrusting (post-25 Ma) below the suture zone.

To explain this distribution I propose that the initial crustal configuration at $25 \mathrm{Ma}$, just before the initiation of thickening of the Arabian crust and its exhumation, resulted from the vertical stacking of three main units: (1) the thinned and flexed Arabian continental crust underthrusted below Central Iran by 50-70 km, (2) the overriding Neyriz ophiolitic complex made up of the oceanic lithospheric mantle emplaced in Late Cretaceous time and (3) the southern distal margin of the Eurasian continental crust corresponding to the Sanandaj-Sirjan Zone, which was essentially thickened during Jurassic and Early Cretaceous time.

To maintain a constant elevation of $2 \mathrm{~km}$ between the uncompensated Zagros Folded Belt and the adjacent domain of the suture zone exhibiting a crustal thickness of $\sim 70 \mathrm{~km}$ and shortening of $37 \%$, one should infer a denser crust $\left(\rho_{\mathrm{c}}=3000 \mathrm{~kg} / \mathrm{m}^{3}\right)$, likely related to the obducted mantle sheet. The predicted initial crustal thickness is of the order of $40-45 \mathrm{~km}$, equivalent to the unthickened part of the Arabian margin (Gök et al.2008). One can infer from these calculations that a simple assumption of inhomogeneously distributed inplane shortening can explain the observed $25 \mathrm{~km}$ Moho deepening beneath the suture zone and the observed topography. 


\section{4.b. Thickening of the Iranian plateau}

To the north of the Sanandaj-Sirjan Zone, the mean Iranian plateau elevation is $1500 \mathrm{~m}$ according to Hatzfeld \& Molnar (2010). Assuming that shortening occurred through Airy compensation, these authors estimated using the same equation in the previous Section that the crustal root would be $10-12 \mathrm{~km}$ to maintain the current topography. They derive an initial crustal thickness of 35-40 km. In an alternative view, they considered that the topography is not fully compensated by a buoyant crustal root but that at least $500 \mathrm{~m}$ could be accounted for by mantle delamination beneath the Iranian plateau.

One available estimate of shortening in Central Iran, north of the Urumieh-Dokhtar Magmatic Arc, is $38 \mathrm{~km}$ (29\%) and is thought to have occurred since $10 \mathrm{Ma}$ (Morley et al. 2009). The current crustal thickness beneath Central Iran, also called Central Domain (CD) in Paul et al. (2010), is $\sim 42 \mathrm{~km}$ or $48 \mathrm{~km}$ close to Alborz according to Radjaee et al. (2010). Assuming Airy compensation, the $\sim 1 \mathrm{~km}$ elevation implies a crustal root of only $5 \mathrm{~km}$, thus suggesting limited crustal shortening of only $14 \%$, which is significantly smaller than the value obtained from the balanced cross-section. Reconciling the observed shortening with the current crustal thickness and elevation requires increasing the average density of the Iranian crust to $\rho_{\mathrm{c}}=3000 \mathrm{~kg} / \mathrm{m}^{3}$. This could be justified if the average composition of the Iranian crust has been substantially modified by magmatic underplating or by Eocene magmatic intrusions well described in the region (e.g. Allen \& Armstrong, 2008). An average initial thickness of $32 \pm 2 \mathrm{~km}$ is obtained. The geological meaning of the crustal thinning is probably two-fold. First, the development of Eocene deep-water basins to the north of the Urumieh-Dokhtar volcanic arc has been already noticed (Vincent et al. 2005 and references therein) and might be related to the regional backarc extension episode (Vincent et al. 2005; Verdel et al. 2007; Morley et al. 2009). Second, a renewed episode of extension during Late Miocene time of unclear geodynamic origin (Morley et al. 2009) surely contributed to the crustal thinning. Finally, given the proposed $29 \%$ of shortening over the entire length of the Iranian plateau (300-450 km), a shortening of $\sim 120-180 \mathrm{~km}$ is obtained to build the current crustal thickness.

\section{4.c. Timing and amount of shortening in the Alborz and the Caspian Sea}

Shortening across the Alborz is estimated to range between 30 and $56 \mathrm{~km}$ (Allen et al. 2003; Guest et al. 2006a) and probably began between $\sim 17 \mathrm{Ma}$, if one considers the increase in accumulation rates (Ballato et al. 2008, 2011), and $12 \mathrm{Ma}$ ago (Guest et al. 2006b) in the Western Alborz or 6-4 Ma in the Central Alborz (Axen et al. 2001) if rapid exhumation is taken into account (Fig. 1b). Shortening associated with the subduction of the Caspian Sea to the north beneath the Apsheron Sill is constrained by the depths of earthquakes of at least $80 \mathrm{~km}$ (Jackson et al. 2002). Considering uncertainties in the timing of subduction initiation, I consider a value of $\sim 75 \mathrm{~km}$ to be accommodated within this region, thus satisfying both the data and the total convergence of $440 \mathrm{~km}$ (Fig. 1a, b).

\section{Discussion and conclusions}

The absence of change in Arabian plate motion since $22 \mathrm{Ma}$ (ArRajehi et al. 2010) just after the decrease from 3 to $2 \mathrm{~cm} \mathrm{yr}^{-1}$ caused by the initiation of crustal thickening in the Zagros implies $440 \mathrm{~km}$ of ArabiaEurasia convergence. This was accommodated since Miocene time across the Zagros belt, Central Iran, the Alborz and the Caspian Sea but not necessarily at the same rate. By taking into consideration the published amounts of long-term shortening and their timing, I suggest that it is possible to reproduce the total convergence predicted by geodetic and plate reconstruction (Fig. 7). If one refers to Figure 2, which is based on the balanced cross-section by Mouthereau et al. (2007) of the Fars arc region and on the study by Agard et al. (2005) to the north of the Lorestan arc region, about $135 \mathrm{~km}$ of convergence has been accommodated by frontal accretion in the Zagros Folded Belt $(15 \mathrm{~km})$, by duplexing (underplating) of Arabian crust below the Sanandaj-Sirjan Zone $(\sim 50 \mathrm{~km})$ and by underthrusting $(\sim 70 \mathrm{~km})$ localized across the Main Zagros Thrust. A maximum shortening of $180 \mathrm{~km}$ is obtained if in-plane shortening of $29 \%$ is assumed to have occurred throughout Central Iran; $50 \mathrm{~km}$ were accommodated across the Alborz and $75 \mathrm{~km}$ were taken up by subduction of the Caspian Sea.

Thermochronologic data and age constraints on the initiation of the siliciclastic sedimentation in the foreland basins reveal that deformation initially concentrated in the Zagros c. $20 \mathrm{Ma}$ (Homke et al. 2009; Gavillot et al. 2010; Khadivi et al. 2010; S. Khadivi, unpub. Ph.D. thesis, Univ. Pierre et Marie Curie, 2010) and in the Alborz approximately at the same time 20-17.5 Ma ago (Ballato et al. 2008, 2011) (Figs 1b, 7).

This stage was followed by propagation of shortening in the Zagros Folded Belt (Khadivi et al. 2010) and uplift in the Zagros after $\sim 12.4 \mathrm{Ma}$ (Figs 1, 7). This timing is concordant with the acceleration of deformation in the Alborz (Guest et al. 2006b), in the Kopet-Dagh and is coeval with the initiation of subduction of the south Caspian Sea (Hollingsworth et al. 2010) and deformation in Central Iran (Morley et al. 2009). Rapid exhumation in the Central Alborz at $\sim 5 \mathrm{Ma}$ (Axen et al. 2001) and coeval onset of increasing accumulation rates in the south Caspian Sea at $5.5 \mathrm{Ma}$ (Allen et al. 2002), though possibly suggesting a younger subduction, also support the regional changes at $15-5 \mathrm{Ma}$ (Figs 1b, 7). 
b

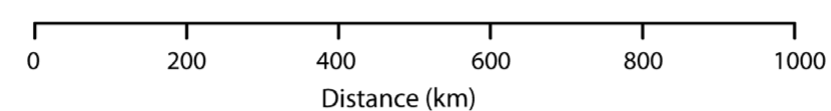

Distance (km)

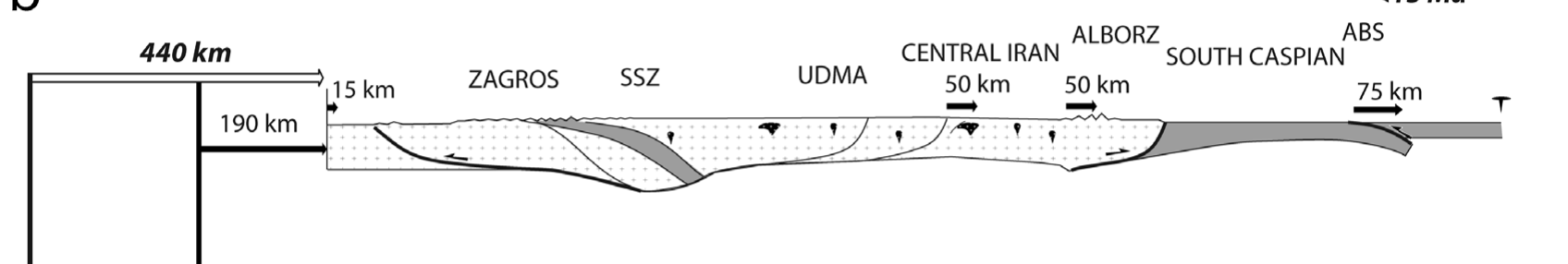

22-15 Ma

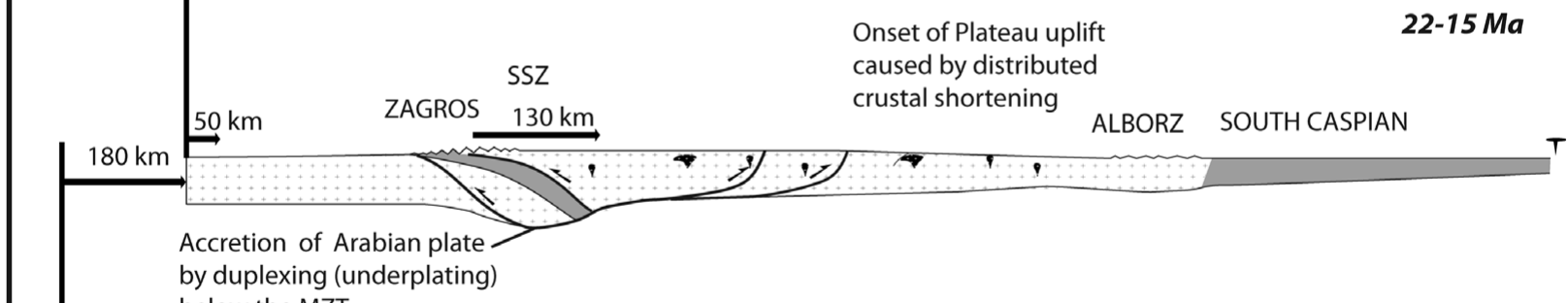

by duplexing (underplating)

below the MZT

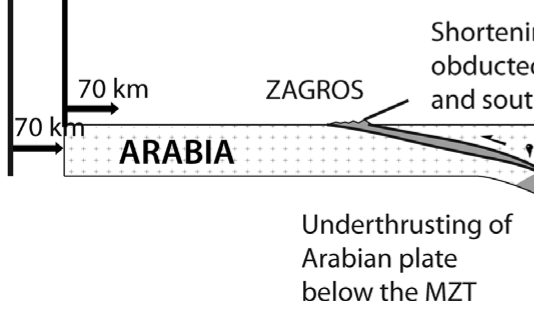

Figure 7. (a) Present-day topography and location of main tectonic belts in the Arabia-Eurasia collision for reference. (b) Distribution of shortening within orogenic belts and the Iranian plateau illustrating how the Arabian-Eurasian plate convergence was accommodated during the last $22 \mathrm{Ma}$. Note the progressive migration of shortening towards the north and in areas originally at low elevation. Abbreviations: SSZ - Sanandaj-Sirjan Zone; UDMA - Urumieh-Dokhtar Magmatic Arc; ABS - Apsheron-Balkan Sill; MZT - Main Zagros Thrust.

I propose that during the past 22 Ma stable motion of Arabia, a shift of localized deformation occurred in Late Miocene-Pliocene times toward the Zagros or the Alborz that were uplifting (Fig. 7). A concomitant decrease of shortening rates in the Iranian plateau occurred to compensate for constant boundary velocity. The insignificant change in Arabian plate motion makes the distribution of crustal shortening and underthrusting during the Arabia/Eurasia convergence the main driver of Zagros mountain and Iranian plateau uplift over the past $20 \mathrm{Ma}$. Slab detachment, which is suspected to be responsible for Miocene-Pliocene magmatic pulses, should therefore be considered with caution if we are to evaluate its contribution to the uplift of the whole Zagros region. I have herein proposed that the current topography of Central Iran can be explained by differences in the initial (i.e. before $20 \mathrm{Ma}$ ) thickness of the continental crust. This thinning of Central Iran is thought to be at least partly caused by a back-arc extensional regime related to the NeoTethyan slab rollback during Eocene time (Vincent et al. 2005; Moritz, Ghazban \& Singer, 2006; Verdel et al. 2007; Morley et al. 2009; Ballato et al. 2011). The Iranian lithosphere was consequently relatively weak and hence shortened at low deviatoric stresses causing the inversion of extensional basins during Early Miocene time until its crust attained its present-day thickness. Because the crust of Central Iran became progressively thicker, the forces necessary to balance the increase of potential energy associated with plateau growth led to the reactivation of surrounding orogenic domains i.e. the Alborz and the Zagros after 12 Ma.

Acknowledgements. Most of the work presented in this paper has benefited from the thesis work of S. Khadivi. I am greatly indebted to G. Simpson and M. Allen for their insightful reviews and the guest editor O. Lacombe for his additional comments that greatly improved the manuscript.

\section{References}

Adams, A., Brazier, R., Nyblade, A., Rodgers, A. J. \& AL-AMRI, A. 2009. Source parameters for moderate earthquakes in the Zagros Mountains with implications for the depth extent of seismicity. Bulletin of the Seismological Society of America 99, 2044-9. 
Agard, P., OMrani, J., Jolivet, L. \& Mouthereau, F. 2005. Convergence history across Zagros (Iran): constraints from collisional and earlier deformation. International Journal of Earth Sciences 94, 401-19.

AhMADHADI, F., LACOMBE, O. \& DANIEL, J. M. 2007. Early reactivation of basement faults in Central Zagros (SW Iran): evidence from pre-folding fracture populations in the Asmari Formation and Lower Tertiary paleogeography. In Thrust Belts and Foreland Basins: From fold kinematics to hydrocarbon systems (eds O. Lacombe, J. Lavé, F. Roure \& J. Vergés), pp. 205-28. SpringerVerlag.

Allen, M. B. \& Armstrong, H. A. 2008. ArabiaEurasia collision and the forcing of mid-Cenozoic global cooling. Palaeogeography, Palaeoclimatology, Palaeoecology 265, 52-8.

Allen, M., GHASSEMI, M. R., Shahrabi, M. \& QORASHI, M. 2003. Accommodation of late Cenozoic oblique shortening in the Alborz range, northern Iran. Journal of Structural Geology 25, 659-72.

Allen, M., Jackson, J. A. \& Walker, R. 2004. Late Cenozoic reorganization of the Arabia-Eurasia collision and the comparison of short-term and longterm deformation rates. Tectonics 23, TC2008, doi: 10.1029/2003TC001530, $16 \mathrm{pp}$.

Allen, M. B., Jones, S., Ismail-ZAdeH, A., Simmons, M. \& ANDERSON, L. 2002. Onset of subduction as the cause of rapid Pliocene-Quaternary subsidence in the South Caspian basin. Geology 30, 775-8.

Allen, M. B., Kheirkhah, M., Emami, M. H. \& Jones, S. J. 2011. Right-lateral shear across Iran and kinematic change in the Arabia-Eurasia collision zone. Geophysical Journal International 184, 555-74.

ArRajehi, A., McClusky, S., ReILINGER, R., DAOUd, M., Alchalbi, A., ErgintaV, S., Gomez, F., Sholan, J., Bou-Rabee, F., OgubazGhi, G., Haileab, B., FisseHA, S., AsfaW, L., MAHMOUd, S., RAYAN, A., BENDIK, R. \& KogAN, L. 2010. Geodetic constraints on presentday motion of the Arabian Plate: implications for Red Sea and Gulf of Aden rifting. Tectonics 29, TC3011, doi:10.1029/2009TC002482, 10 pp.

Axen, G., Lam, P. S., Grove, M., Stockli, D. F. \& HASSANZADEH, J. 2001. Exhumation of the westcentral Alborz Mountains, Iran, Caspian subsidence, and collision-related tectonics. Geology 29, 559-62.

BAllato, P., NOWACZYK, N. R., LANDGRAF, A., STRECKER, M. R., Friedrich, A. \& TABAtABAEI, S. H. 2008. Tectonic control on sedimentary facies pattern and sediment accumulation rates in the Miocene foreland basin of the southern Alborz mountains, northern Iran. Tectonics 27, TC6001, doi:10.1029/2008TC002278, 20 pp.

Ballato, P., UbA, C. E., LANDGRAF, A., Strecker, M. R., Sudo, M., Stockli, D., Friedrich, A. \& TABATABAEI, S. H. 2011. Arabia-Eurasia continental collision: insights from late Tertiary foreland-basin evolution in the Alborz Mountains, northern Iran. Geological Society of America Bulletin 123, 106-31.

BERBERIAN, F. \& BERBERIAN, M. 1981. Tectono-plutonic episodes in Iran. In Zagros-Hindu Kush-Himalaya Geodynamic Evolution, vol. 3 (eds H. K. Gupta \& F. M. Delany), pp. 5-32. Washington, D.C.: American Geophysical Union.

Berberian, M. \& King, G. C. P. 1981. Towards a paleogeography and tectonic evolution of Iran. Canadian Journal of Earth Sciences 18, 210-65.

Berberian, F., Muir, I. D., PANKHURSt, R. J. \& Berberian, M. 1982. Late Cretaceous and early Miocene Andean- type plutonic activity in northern Makran and Central Iran. Journal of the Geological Society, London 139, 605-14.

Blanc, E. J.-P., Allen, M. B., Inger, S. \& Hassani, H. 2003. Structural styles in the Zagros simple folded zone, Iran. Journal of the Geological Society, London 160, 401-12.

FAKHARI, M. D., AXEN, G. J., HORTON, B. K., HASSANZADEH, J. \& AMINI, A. 2008. Revised age of proximal deposits in the Zagros foreland basin and implications for Cenozoic evolution of the High Zagros. Tectonophysics 451, 170 85.

Gavillot, Y., Axen, G. J., Stockli, D. F., Horton, B. K. \& FAKHARI, M. D. 2010. Timing of thrust activity in the High Zagros fold-thrust belt, Iran, from (U-Th)/He thermochronometry. Tectonics 29, TC4025, doi:10.1029/2009TC002484, 25 pp.

GöK, R., MAHDI, H., AL-SHUKRI, H. \& RodGers, A. J. 2008. Crustal structure of Iraq from receiver functions and surface wave dispersion: implications for understanding the deformation history of the Arabian-Eurasian collision. Geophysical Journal International 172, 1179-87.

GolONKA, J. 2004. Plate tectonic evolution of the southern margin of Eurasia in the Mesozoic and Cenozoic. Tectonophysics 381, 235-73.

Guest, B., AXen, G. J., LAM, P. S. \& HassanzadeH, J. 2006a. Late Cenozoic shortening in the westcentral Alborz Mountains, northern Iran, by combined conjugate strike-slip and thin-skinned deformation. Geosphere 2, 35-52.

Guest, B., Stockli, D. F., Grove, M., AXen, G. J., Lam, P. \& HASSANZADEH, J. 2006 $b$. Thermal histories from the central Alborz Mountains, northern Iran: implications for the spatial and temporal distribution of deformation in northern Iran. Geological Society of America Bulletin 118, 1507-21.

Harzhauser, M., Kroh, A., Mandic, O., Piller, E. W., GoHlich, U., Reuter, M. \& Berning, B. 2007. Biogeographic responses to geodynamics: a key study all around the Oligo-Miocene Tethyan Seaway. Zoologischer Anzeiger 246, 241-56.

HATZFELD, D. \& MolNAR, P. 2010. Comparisons of the kinematics and deep structures of the Zagros and Himalaya and of the Iranian and Tibetan plateaus and geodynamic implications. Review of Geophysics 48, RG2005, doi:10.1029/2009RG000304, 48 pp.

HatzFeld, D., Tatar, M., Priestley, K. \& GhaforiAshtiany, M. 2003. Seismological constraints on the crustal structure beneath the Zagros Mountain Belt (Iran). Geophysical Journal International 155, 40310.

Hollingsworth, J., FATTAhi, M., WALKER, R., TALEBIAN, M., BAHroudi, A., BolourChI, M. J., JACKSON, J. \& COPLEY, A. 2010. Oroclinal bending, distributed thrust and strike-slip faulting, and the accommodation of Arabia-Eurasia convergence in NE Iran since the Oligocene. Geophysical Journal International 181, $1214-46$.

HOLLINGSWORTH, J., JACKSON, J., WALKER, R., GHEITANCHI, M. R. \& BolOURCHI, M. J. 2006. Strike-slip faulting, rotation, and along-strike elongation in the Kopeh Dagh mountains, NE Iran. Geophysical Journal International 166, 1161-77.

Homke, S., Vergés, J., GARCÉS, M., EMAMI, H. \& KARPUZ, R. 2004. Magnetostratigraphy of Miocene-Pliocene Zagros foreland deposits in the front of the Push-e Kush Arc (Lurestan Province, Iran). Earth and Planetary Science Letters 225, 397-410. 
Homke, S., Verges, J., Serra-Kiel, J., Bernaola, G., Sharp, I., GARCES, M., Montero-Verdu, I., KARPUZ, R. \& GOODARZI, M. H. 2009. Late CretaceousPaleocene formation of the proto-Zagros foreland basin, Lurestan Province, SW Iran. Geological Society of America Bulletin 121, 963-78.

Homke, S., Vergès, J., Van Der Beek, P. A., Fernandez, M., SAura, E., BARbero, L., Badics, B. \& Labrin, E. 2010. Insights in the exhumation history of the NW Zagros from bedrock and detrital apatite fissiontrack analysis: evidence for a long-lived orogeny. Basin Research 22, 659-80.

Horton, B. K., Hassanzadeh, J., Stockli, D. F., Axen, G. J., GILlis, R. J., Guest, B., AMINI, A., FAKHARI, M., ZAMANZADEH, S. M. \& GROVE, M. 2008. Detrital zircon provenance of Neoproterozoic to Cenozoic deposits in Iran: implications for chronostratigraphy and collisional tectonics. Tectonophysics 451, 97-122.

Jackson, J., Priestley, K., Allen, M. \& Berberian, M. 2002. Active tectonics of the South Caspian Basin. Geophysical Journal International 148, 214 45.

JAMES, G. A. \& WyND, J. G. 1965. Stratigraphic nomenclature of Iranian oil consortium agreement area. American Association of Petroleum Geologists Bulletin 49, 2162-245.

Kaviani, A., Hatzfeld, D., Paul, A., Tatar, M. \& PRIESTLEY, K. 2009. Shear-wave splitting, lithospheric anisotropy, and mantle deformation beneath the ArabiaEurasia collision zone in Iran. Earth and Planetary Science Letters 286, 371-8.

Kaviani, A., Paul, A., Bourova, E., Hatzfeld, D., Pedersen, H. \& MoKhtari, M. 2007. A strong seismic velocity contrast in the shallow mantle across the collision zone (Iran). Geophysical Journal International 171, 399-410.

Khadivi, S., Mouthereau, F., LARrasoaña, J. C., VergÉS, J., Lacombe, O., Khademi, E., Beamud, E., MelinteDOBRINESCU, M. \& SUC, J.-P. 2010. Magnetochronology of synorogenic Miocene foreland sediments in the Fars arc of the Zagros Folded Belt (SW Iran). Basin Research 22, 918-32.

Lacombe, O., Amrouch, K., Mouthereau, F. \& Dissez, L. 2007. Calcite twinning constraints on late Neogene stress patterns and deformation mechanisms in the active Zagros collision belt. Geology 35, 263-6.

Lacombe, O., Mouthereau, F., Kargar, S. \& Meyer, B. 2006. Late Cenozoic and modern stress fields in the western Fars (Iran): implications for the tectonic and kinematic evolution of central Zagros. Tectonics 25, TC1003, doi:10.1029/2005TC001831, 27 pp.

LETERRIER, J. 1985. Mineralogical geochemical and isotopic evolution of two Miocene mafic intrusions from the Zagros (Iran). Lithos 18, 311-29.

LYBERIS, N. \& MANBY, G. 1999. Oblique to orthogonal convergence across the Turan block in the post-Miocene. American Association of Petroleum Geologists Bulletin 83, 1135-60.

Maggi, A. \& Priestley, K. 2005. Surface waveform tomography of the Turkish-Iranian Plateau. Geophysical Journal International 160, 1068-80.

Masson, F., Chéry, J., HatzFeld, D., Martinod, J., VERnANT, P., TAVAKOli, F. \& GHAFORY-Ashtiani, M. 2005. Seismic versus aseismic deformation in Iran inferred from earthquakes and geodetic data. Geophysical Journal International 160, 217-26.

Mazhari, S. A., BeA, F., Amini, S., Ghalamghash, J., Molina, J. F., Montero, P., Scarrow, J. H. \&
Williams, I. S. 2009. The Eocene bimodal Piranshahr massif of the Sanandaj-Sirjan Zone, NW Iran: a marker of the end of the collision in the Zagros orogen. Journal of the Geological Society, London 166, 53-69.

McClusky, S., ReILINGER, R., MAHMOUd, S., BEN SARI, D. \& TealeB, A. 2003. GPS constraints on Africa (Nubia) and Arabia plate motions. Geophysical Journal International 155, 126-38.

MCQUARRIE, N. 2004. Crustal scale geometry of the Zagros fold-thrust belt, Iran. Journal of Structural Geology 26, 519-35.

McQuarrie, N., Stock, J. M., Verdel, C. \& Wernicke, B. P. 2003. Cenozoic evolution of Neotethys and implications for the causes of plate motions. Geophysical Research Letters 30, 2036, doi:10.1029/2003GL017992, $4 \mathrm{pp}$.

Molinaro, M., Guezou, J. C., Leturmy, P., Eshraghi, S. A. \& FRIzON DE LAMOTTE, D. 2004. The origin of changes in structural style across the Bandar Abbas syntaxis, SE Zagros (Iran). Marine and Petroleum Geology 21, 735-52.

Molinaro, M., Leturmy, P., Guezou, J.-C., Frizon DE LAmotte, D. \& Eshraghi, S. A. 2005. The structure and kinematics of the south-eastern Zagros fold-thrust belt; Iran: from thin-skinned to thick-skinned tectonics. Tectonics 24, TC3007, doi:10.1029/2004TC001633, $19 \mathrm{pp}$.

Moritz, R., Ghazban, F. \& Singer, B. 2006. Eocene Gold Ore Formation at Muteh, Sanandaj-Sirjan Tectonic Zone, Western Iran: a result of late-stage extension and exhumation of metamorphic basement rocks within the Zagros orogen. Economic Geology 101, 1497-524.

Morley, C. K., Kongwung, B., Julapour, A. A., ABDOlghafourian, M., HaJiAn, M., WAPles, D., WARren, J., OtTERdoOM, H., SRISURIYON, K. \& KAZEMI, H. 2009. Structural development of a major late Cenozoic basin and transpressional belt in central Iran: the Central Basin in the Qom-Saveh area. Geosphere 5, 325-62.

Mouthereau, F., Lacombe, O. \& Meyer, B. 2006. The Zagros Folded Belt (Fars, Iran): constraints from topography and critical wedge modelling. Geophysical Journal International 165, 336-56.

Mouthereau, F., Tensi, J., Bellahsen, N., Lacombe, O., De Boisgrollier, T. \& Kargar, S. 2007. Tertiary sequence of deformation in a thin-skinned/thick-skinned collision belt: the Zagros Folded Belt (Fars, Iran). Tectonics 26, TC5006, doi:10.1029/2007TC002098, $28 \mathrm{pp}$.

Nilforoushan, F., Masson, F., Vernant, P., Vigny, C., MARTINOD, J., ABBASSI, M., NANKALI, H., HATZFELD, D., Bayer, R., Tavakoli, F., Ashtiani, A., DoerFlinger, E., Daignières, M., Collard, P. \& ChÉRY, J. 2003. GPS network monitors the Arabia-Eurasia collision deformation in Iran. Journal of Geodesy 77, 411-22.

Nissen, E., YAmini-Fard, F., TAtar, M., GHOlamzadeh, A., Bergman, E., Elliott, J. R., JaCKsOn, J. A. \& PARSONS, B. 2010. The vertical separation of mainshock rupture and microseismicity at Qeshm island in the Zagros fold-and-thrust belt, Iran. Earth and Planetary Science Letters 296, 181-94.

OKAY, A. I., ZatTin, M. \& CAVAZZA, W. 2010. Apatite fission-track data for the Miocene Arabia-Eurasia collision. Geology 38, 35-8.

Omrani, J., Agard, P., Whitechurch, H., Benoit, M., Prouteau, G. \& Jolivet, L. 2008. Arc-magmatism and subduction history beneath the Zagros Mountains, Iran: 
a new report of adakites and geodynamic consequences. Lithos 106, 380-98.

Oveisi, B., Lavé, J., VAN Der BeeK, P., Carcaillet, J., Benedetti, L. \& Aubourg, C. 2009. Thick- and thin-skinned deformation rates in the central Zagros simple folded zone (Iran) indicated by displacement of geomorphic surfaces. Geophysical Journal International 176, 627-54.

Paul, A., Hatzfeld, D., Kaviani, A., Tatar, M. \& Pequegnat, C. 2010. Seismic imaging of the lithospheric structure of the Zagros mountain belt (Iran). In Tectonic and Stratigraphic Evolution of the Zagros and Makran During the Meso-Cenozoic (P. Leturmy \& C. Robin), pp. 5-18. Geological Society of London, Special Publication no. 330.

Paul, A., Kaviani, A., Hatzfeld, D., Vergne, J. \& MOKHTARI, M. 2006. Seismological evidence for crustal-scale thrusting in the Zagros mountain belt (Iran). Geophysical Journal International 166, 227-37.

PriestLeY, K. \& MCKenZIE, D. 2006. The thermal structure of the lithosphere from shear wave velocities. Earth and Planetary Science Letters 244, 285-301.

RACHIDNEJAD-OMRAN, N., EMAMI, M. H., SABZEHEI, M., Rastad, E., Bellon, H. \& PiQué, A. 2002. Lithostratigraphie et histoire paléozoïque à paléocène des complexes métamorphiques de la région de Muteh, zone de Sanandaj-Sirjan (Iran méridional). Comptes Rendus de l'Académie des Sciences 334, 1185-91.

RADJAeE, A., RHAM, D., MOKhTARI, M., TATAR, M., PRIESTLEY, K. \& HATZFELD, D. 2010. Variation of Moho depth in the central part of the Alborz Mountains, northern Iran. Geophysical Journal International 181, 173-84.

Roustaei, M., Nissen, E., ABAssi, M., GHOlamzadeh, A., GHORASHI, M., TATAR, M., YAMINI-FARD, F., BERGMAN, E., JACKSON, J. \& PARSONS, B. 2010. The 2006 March 25 Fin earthquakes (Iran)-insights into the vertical extents of faulting in the Zagros Simply Folded Belt. Geophysical Journal International 181, 1275-91.

SCHUSTER, F. \& WIELANDT, U. 1999. Oligocene and Early Miocene coral faunas from Iran: palaeoecology and palaeobiogeography. International Journal of Earth Sciences 88, 571-81.

Shafail Moghadam, H., Stern, R. J. \& Rahgoshay, M. 2010. The Deshir ophiolite (central Iran): geochemical constraints on the origin and evolution of the Inner Zagros ophiolitic belt. Geological Society of America Bulletin 122, 1516-47.
SHERKATI, S. \& LETOUZEY, J. 2004. Variation of structural style and basin evolution in the central Zagros (Izeh zone and Dezful Embayment), Iran. Marine and Petroleum Geology 21, 535-54.

SHERKATI, S., LETOUZEY, J. \& FRIZON DE LAMOTTE, D. 2006. Central Zagros fold-thrust belt (Iran): new insights from seismic data, field observation, and sandbox modeling. Tectonics 25, TC4007, doi:10.1029/2004TC001766, $27 \mathrm{pp}$.

SNYDER, D. B. \& BARAZANGI, M. 1986. Deep crustal structure and flexure of the Arabian plate beneath the Zagros collisional mountain belt as inferred from gravity observations. Tectonics 5, 361-73.

StOCKLIN, J. 1968. Structural history and tectonics of Iran; a review. American Association of Petroleum Geologists Bulletin 52, 1229-58.

TALEBIAN, M. \& JACKSON, J. A. 2004. A reappraisal of earthquake focal mechanisms and active shortening in the Zagros mountains of Iran. Geophysical Journal International 156, 506-26.

TAtar, M., HATZFEld, D., MARTINOD, J., WALPersdorf, A., GHAFori-Ashtiany, M. \& CHÉRY, J. 2002. The present-day deformation of the central Zagros from GPS measurements. Geophysical Research Letters 29, 1927, doi:10.1029/2002GL015427, 4 pp.

VERDEL, C., WERNICKE, B. P., RAMEZANI, J., HASSANZADEH, J., RenNe, P. R. \& SPELl, T. L. 2007. Geology and thermochronology of Tertiary Cordilleran-style metamorphic core complexes in the Saghand region of central Iran. Geological Society of America Bulletin 119, 961-77.

Vernant, P., Nilforoushan, F., HatzFeld, D., ABbassi, M. R., VignY, C., MASSON, F., NANKALI, H., MARTINOD, J., ASHTIANI, A., BAYER, R., TAVAKOli, F. \& CKAET, J. 2004. Present-day crustal deformation and plate kinematics in the Middle East constrained by GPS measurements in Iran and northern Oman. Geophysical Journal International 157, 381-98.

Vincent, S. J., Allen, M. B., IsMAil-Zadeh, A. D., Flecker, R., Foland, K. A. \& Simmons, M. D. 2005. Insights from the Talysh of Azerbaijan into the Paleogene evolution of the South Caspian region. Geological Society of America Bulletin 117, 1513-33.

WALPERSDORF, A., HATZFELD, D., NANKALI, H., TAVAKOLI, F., Nilforoushan, F., Tatar, M., Vernant, P., Chery, J. \& MASSON, F. 2006. Difference in the GPS deformation pattern of North and Central Zagros (Iran). Geophysical Journal International 167, 1077-88. 